\title{
About this dictionary
}

\section{Who this dictionary is for and how to use it}

This dictionary is intended for two main audiences, who may want to find in it different types of information. The first intended audience is the Vurës language community. I hope they will be able to use this dictionary to help them write their language, and to promote and maintain the use of traditional words and meanings. It was for this audience, particularly the younger members, that I decided to include many colour photos, especially to illustrate plant and animal names, and a thesaurus, that teachers will be able to refer to when working with school children. The second main audience is linguists and other scientists, for whom I have included more extensive fields that may not be relevant for community members, such as etymologies and literal meanings.

There is a lot of information packed into some of the entries in the dictionary, so Vurës speakers who are not very familiar with using a dictionary should read the explanations in the following sections. These show how to use the dictionary and how different parts of an entry for a word are separated. After a brief introduction to the Vurës language in Section 2, the Vurës spelling system is explained in Section 2.1. Section 2.2 provides a brief note about punctuation. This is a trilingual dictionary, with definitions of Vurës words presented in both English and Bislama, the national language of Vanuatu. Some information about the Bislama used in the dictionary is provided in Section 3. Section 4 presents some background information about the Vurës corpus and how the dictionary was compiled. Section 5 explains how the dictionary, and entries within the dictionary, are structured, and how to find information. Section 5.1 details the alphabetical ordering that is used. In section 5.2 some sample entries are presented to illustrate and explain how entries are set out. Some details about the part of speech labels that are used in the dictionary are given in Section 5.3. Section 5.4 discusses variants and complex word forms. The final section comments on word origins. 


\section{The Vurës language}

Vurës is a language spoken by about 2,000 people who live mostly in the southern part of the island of Vōnō Lav - called Vanua Lava by outsiders - in Vanuatu, a small island nation in the South Pacific (Malau 2016). Map 1 shows the location of Vanua Lava, in the Banks group of islands, part of Torba, the most northerly province of Vanuatu. Map 2 shows just Vanua Lava, the shaded part indicating the area where Vurës is spoken, with labels for the main Vurës-speaking villages. Around half of the people who speak Vurës live in the large village of Vētuboso. The remainder live mostly in villages up to an hour or two walk away from Vètuboso, with small communities of speakers also in the major Vanuatu towns of Port Vila, the capital, and Luganville, on the island of Espiritu Santo.

The most recent count puts the number of vernacular languages of Vanuatu at 138, with 17 of these spoken in the islands of Torba province (François et al. 2015). Vurës, along with all other indigenous languages of Vanuatu, belongs to the Oceanic subgroup of languages, which in turn are all part of the larger language family called Austronesian. Within the Oceanic subgroup, languages of Vanuatu are all part of the Southern Oceanic linkage, which is divided into several groups, and Vurës, like all languages spoken in Torba province, is part of the Northern Vanuatu linkage (Lynch 2000; Lynch, Ross and Crowley 2002).

Vurës speakers are multilingual, and are all fluent in Bislama, which is an English-lexifier creole (Crowley 2003, 2004). Many speakers also have some level of proficiency in the other main language of Vanua Lava, Vera'a and/or one of the languages of neighbouring islands, such as Mwotlap or Mota. Many Vurës people also have a working knowledge of English, and some have knowledge of French. For most, literacy was taught in English, and people have varying literacy levels in English, French and Bislama. Most people have not been taught how to read and write in their own language and thus find it difficult to transfer their English literacy skills to Vurës. This dictionary aims to help speakers overcome these difficulties. 


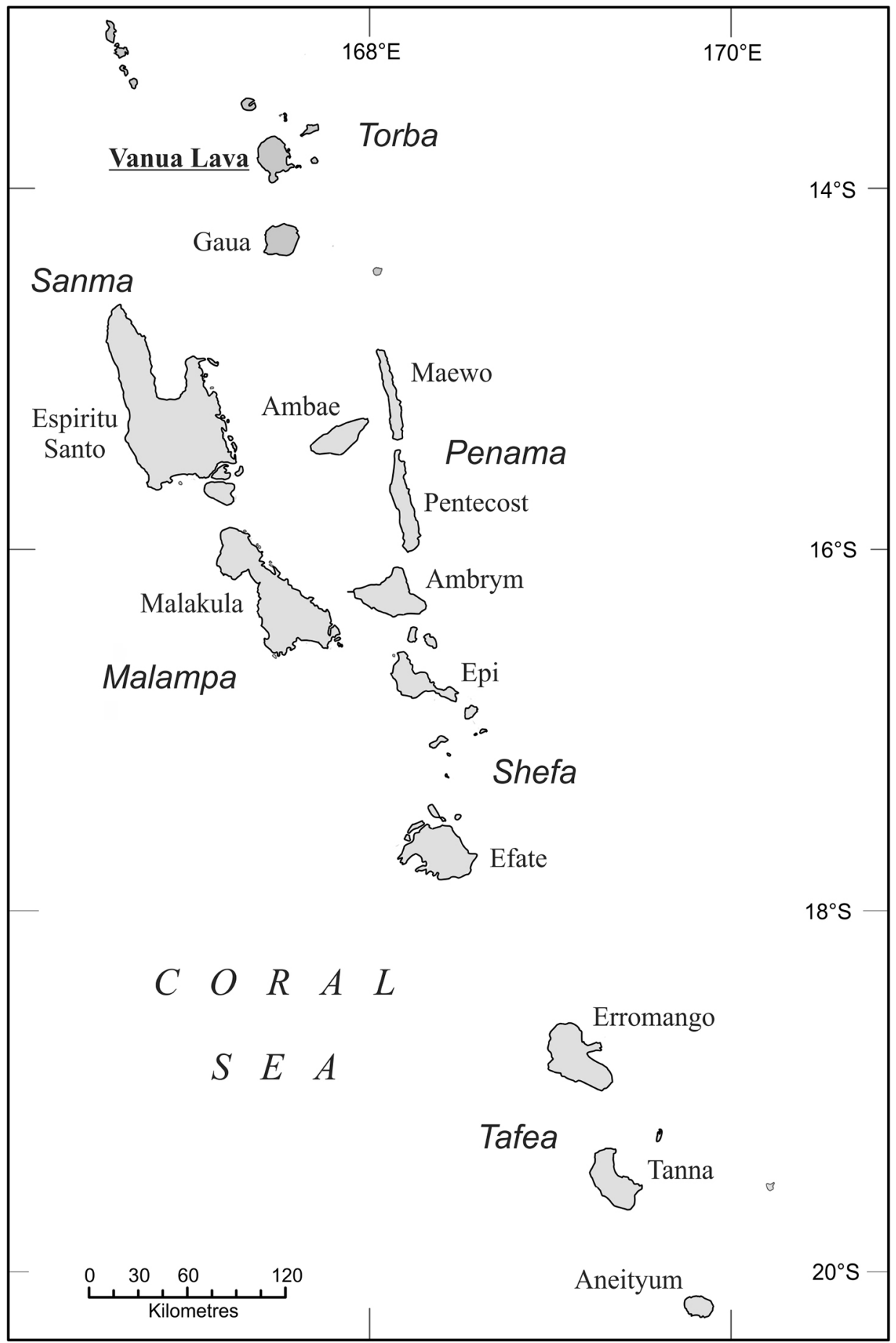

Map 1: Area map of Vanuatu, showing Vanua Lava in the north

Source: () Malau (2016) 


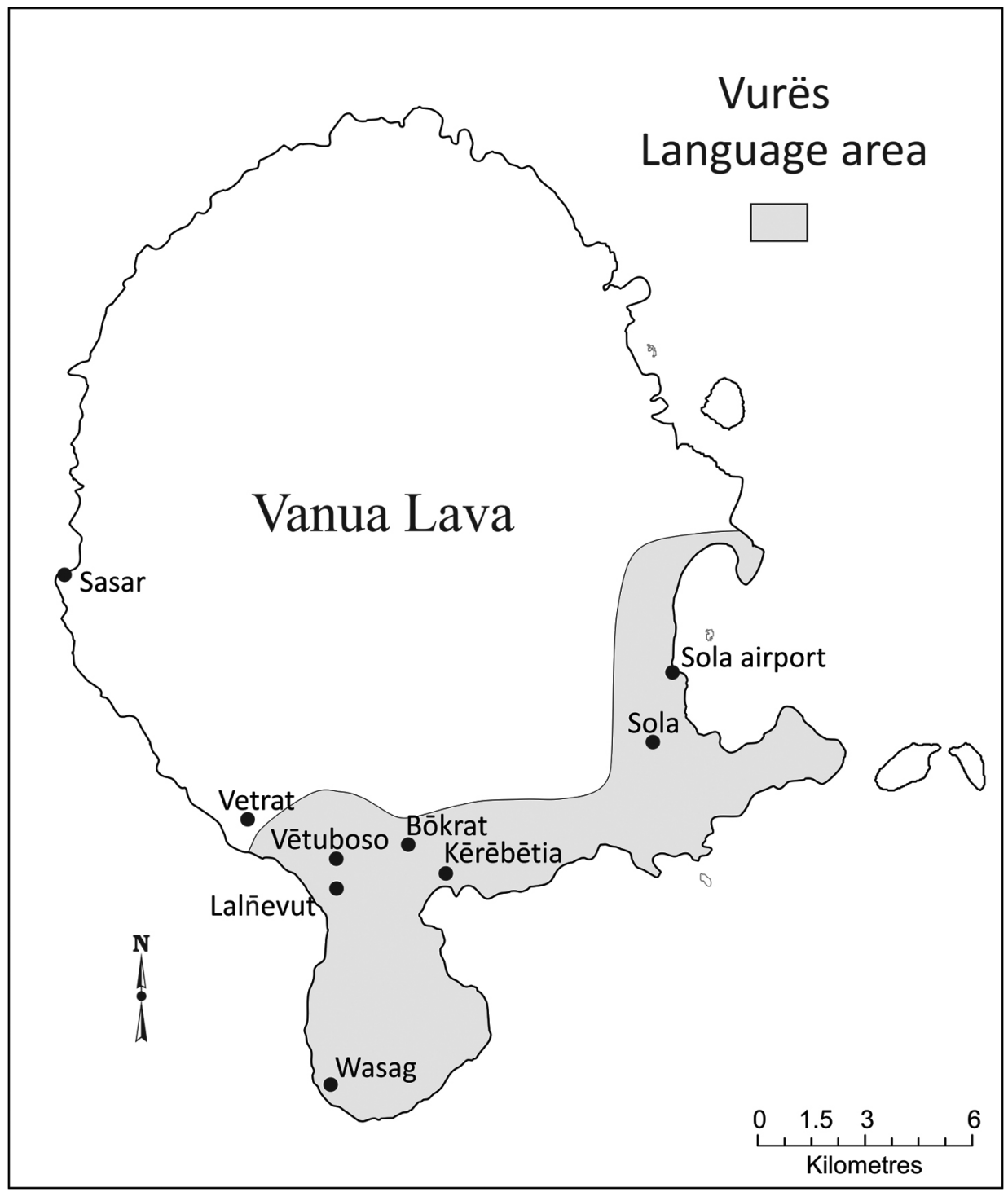

Map 2: Vanua Lava, showing area where Vurës is spoken

Source: (c) Malau (2016)

\subsection{Vurës sounds and spelling}

There is no established tradition of writing in the Vurës language. Most speakers of Vurës have been taught how to read and write in English during their schooling, and have never been taught how to read and write their own language. This has been the norm in schools throughout Vanuatu, with only English and French being used as languages of education. The situation is changing, however, the 2012 Vanuatu National Language Policy (Ministry of Education 2012) stipulates 
that all children should be taught in their mother tongue for the first three years of primary school, with English or French only introduced in Year 3. As of 2016, this policy has begun to be implemented at the Sanlañ primary school, the main school within the Vurës-speaking area. In 2016, as part of the Vanuatu Education Support Program, I assisted with the translation of 51 readers and story books, along with other literacy materials such as posters, for classroom use for Years 1-3 of primary school. The literacy materials that have been produced for Vurës follow the spelling system outlined and used in this dictionary.

Table 1 presents the letters of the Vurës alphabet matched with symbols for the sounds that they represent. Each letter of the alphabet is presented in the first column of the table. In the next column is an example of a Vurës word that has that letter in it. The example words can be used by Vurës speakers as keywords to serve as a reminder of the sound that some of the more unfamiliar letters represent, especially those with marks on top of them, such as $\overline{\mathbf{e}}$ and $\ddot{\mathbf{e}}$. In the last column is a symbol from the International Phonetic Alphabet (IPA), which specifies the sound that the alphabet letter represents. The IPA symbols are to help those who do not already know how to speak Vurës, to show them how words are pronounced. More information about the sounds and phonology of the language can be found in Malau (2016: 19-48), which is a grammar of Vurës.

Table 1: Spelling conventions for Vurës

\begin{tabular}{|c|c|c|}
\hline Letter & Example & Sound \\
\hline $\mathbf{A} \mathbf{a}$ & añañ 'yellow' & [a] \\
\hline $\mathbf{B} \mathbf{b}$ & bibis 'roll up' & {$\left[\mathrm{b},{ }^{\mathrm{m}} \mathrm{b}\right]$} \\
\hline D d & dödöm 'think' & {$\left[\mathrm{d},{ }^{\mathrm{n}} \mathrm{d}\right]$} \\
\hline Ee & es 'spear' (vt.) & {$[\varepsilon]$} \\
\hline$\overline{\mathbf{E}} \overline{\mathbf{e}}$ & ès 'alive' & [e] \\
\hline$\ddot{\mathbf{E}} \ddot{\mathbf{e}}$ & ës 'smoke' & {$[œ]$} \\
\hline $\mathbf{G} \mathbf{g}$ & gegen 'sharp' & {$[\mathrm{\gamma}]$} \\
\hline $\mathbf{I} \mathbf{i}$ & ilsi 'end' & [i] \\
\hline $\mathbf{K} \mathbf{k}$ & kakaka 'story' & {$\left[\mathrm{k}, \mathrm{k}^{\mathrm{h}}\right]$} \\
\hline $\mathbf{L} 1$ & lelev 'fast' & {$[1]$} \\
\hline M m & mamas 'dry' & {$[\mathrm{m}]$} \\
\hline$\overline{\mathbf{M}} \overline{\mathbf{m}}$ & '̄̄ō̄o 'tame' & {$\left[\tilde{y m}^{\mathrm{w}}\right]$} \\
\hline $\mathbf{N} \mathbf{n}$ & nonor 'yesterday' & {$[\mathrm{n}]$} \\
\hline$\overline{\mathbf{N}} \overline{\mathbf{n}}$ & n̄ōōōorr 'snore' & {$[\mathrm{y}]$} \\
\hline 0 o & on 'large octopus' & [0] \\
\hline$\overline{\mathbf{o}} \overline{\mathbf{o}}$ & ōn 'sand' & [o] \\
\hline$\ddot{0 ̈ ~ o ̈ ~}$ & götö 'hermit crab’ & [ø] \\
\hline
\end{tabular}




\begin{tabular}{|l|l|l|}
\hline Letter & Example & Sound \\
\hline P p & Pōpō 'Grandma, Grandpa' & {$[\mathrm{p}]^{1}$} \\
\hline Q q & qaqaq 'talk' & {$\left[\widehat{k p}^{\mathrm{w}}\right]$} \\
\hline R r & rörö 'news' & {$[\mathrm{r}, \mathrm{c}]$} \\
\hline S s & sasar 'island cabbage' & {$[\mathrm{s}]$} \\
\hline T t & Tatat 'Uncle' & {$\left[\mathrm{t}, \mathrm{t}^{\mathrm{h}}\right]$} \\
\hline U u & usuk 'my life' & {$[\mathrm{y}, \mathrm{v}]^{2}$} \\
\hline V v & vivi 'umbrella' & {$[\beta, \mathrm{p}]$} \\
\hline W w & wiwieg 'work' & {$[\mathrm{w}]$} \\
\hline
\end{tabular}

There are some difficult aspects of the spelling system. When I first started documenting Vurës in 1999, there were no books or other materials published in the Vurës language and few people ever tried to write in the language. When people needed to write anything, they would mainly write in English or Bislama. Eli Field Malau, one of the main people who has helped me to document the language, was one of a very few people who had tried to write in Vurës. He had faced difficulties with how to write the sounds that do not occur in English or Bislama, such as the vowels that we now write as $\ddot{\mathbf{e}}$ and $\ddot{\mathbf{o}}$. We were assisted in the development of the spelling system by linguist Alexandre François.

As people are familiar with writing in English, if a Vurës sound is fairly similar to an English sound, then it is easy to use the same letter that is used for English. This is the case for a lot of the sounds of Vurës, even if the sound is a little different. For example, a Vurës $\mathbf{v}$ is made by putting both lips together, whereas an English $\mathbf{v}$ is made by moving the bottom lip up to the top teeth. These sounds are similar enough that it makes sense to use $\mathbf{v}$ for both. Several other sounds, mostly some of the vowels, are more difficult. There are also a few consonants that present some difficulties. I'll explain each of the issues here.

To start with the consonants, Table 1 shows that there are two letters that have a line on top, $\overline{\mathbf{m}}$ and $\overline{\mathbf{n}}$. The letter $\overline{\mathbf{m}}$ sounds a bit like an English $\mathbf{m}$ followed by $\mathbf{w}$ and $\overline{\mathbf{n}}$ sounds like English $\mathbf{n g}$. Therefore, we could have decided to write these sounds with $\mathbf{m w}$ instead of $\overline{\mathbf{m}}$ and $\mathbf{n g}$ instead of $\overline{\mathbf{n}}$. Eli Malau and I decided, with input from some interested members of the community, on $\overline{\mathbf{m}}$ and $\overline{\mathbf{n}}$ because quite a lot of older people are familiar with these two symbols being used for Mota language, which has been used as a common language by the Anglican church in the northern islands of Vanuatu for over a hundred years. There was also a sense within the group who participated in discussions that using the

\footnotetext{
1 In Vurës /p/ only occurs in words borrowed from Bislama or English, like pomken 'pumpkin'. It is included here as there are some entries in the dictionary of words beginning with $\mathbf{p}$ that have been fully incorporated into the language.

2 The letter $\mathbf{u}$ represents two different sounds. The sound [v] only occurs in a very few words that come from Mota, like bulsal 'friend'. The decision was therefore made not to introduce a new letter for this sound.
} 
$\overline{\mathbf{m}}$ and $\overline{\mathbf{n}}$ instead of $\mathbf{m w}$ and $\mathbf{n g}$ gives the written language a distinctive Torba character, in contrast with the spelling used for some of the languages spoken on islands to the south.

Over the past 20 years, Eli Malau and I have held various workshops aimed at teaching the proposed spelling system to community members. Armstrong Malau, Eli's son, has continued these literacy teaching efforts through a Facebook group. There has been a reasonable level of interest in our efforts, with perhaps 20 per cent of the community engaging in one way or another. There has been general acceptance of the alphabet that we have proposed by the people who have engaged with us in our literacy teaching efforts. When we have explained the need for symbols that differ slightly from those used for English, the reasoning has been understood and accepted. Today, many speakers of Vurës have become familiar to some extent with using this spelling system, but many other speakers have not. This means that in some cases, when a Vurës speaker tries to write in Vurës without having been taught, they might make different decisions about how to write a sound, based on the language(s) that they already know how to write. The most common difference is choosing $\mathbf{m w}$ instead of $\overline{\mathbf{m}}$ and $\mathbf{n g}$ instead of $\overline{\mathbf{n}}$. People do this to some extent because these are easier to type on computers and smart phones, without needing to put a line on top of the letters. This would be an argument in favour of using $\mathbf{m w}$ and $\mathbf{n g}$. However, this dictionary reflects the earlier community decision. The main reason for this is that the members of the community who I have worked with most closely feel strongly that the orthography has become established, through the literacy materials that we have produced and through community teaching.

The other difficult letter in Vurës is q. This represents a sound which is not close to any sound of English, French or Bislama. It sounds a little bit like English $\mathbf{k}$ and $\mathbf{p}$ said at the same time, then followed by $\mathbf{w}$, all in one sound. So in some ways it is similar to English qu which is pronounced as $\mathbf{k}$ followed by $\mathbf{w}$. For that reason, we use $\mathbf{q}$ for this sound, and also because the letter $\mathbf{q}$ isn't needed for any other sound in Vurës.

As for the vowels, the letters $\mathbf{a}$ and $\mathbf{i}$ are fairly straightforward and close to English and Bislama sounds. The sound represented by letter $\mathbf{u}$ is like a French $\mathbf{u}$ rather than an English one. That is, the letter represents the high front rounded vowel [y]. The symbols based on letters e and $\mathbf{o}$, each with a line on top or two dots on top, are the difficult ones for people to learn which symbol goes with which sound. What is important to realise is that it is always best for a spelling system to have a different letter for each sound, and in Vurës each of these letters does represent a different sound. If you want to write that your grandmother is ēs 'alive' but you write instead that she is ës 'smoke', then obviously that could be a bit confusing!

There are nine vowel sounds in Vurës, but only five vowel letters in the English alphabet, so somehow the English alphabet needed to be adapted so that the Vurës alphabet has a different symbol for each vowel sound. An alternative option would be to use diagraphs, which is when two letters together represent 
one sound, such as in English 'bee'. Many literacy experts believe that it is easier for people learning how to read if each sound has just a single symbol to represent it, rather than two letters together. So this thinking influenced the choice of the symbols.

\subsection{Vurës punctuation notes}

As speakers of Vurës are literate mostly in English, it makes sense to generally follow principles of English punctuation where relevant, like capital letters at the beginning of a sentence and full stops at the end. One punctuation issue of relevance to the format of the dictionary is capitalisation. Headwords for nouns referring to place names, or people's names and kinterms used to address people, belong respectively to the subclasses of absolute location nouns and proper nouns. These nouns are listed capitalised in the dictionary, as they would be written.

There are several proclitics in the language. Proclitics are words that in some ways sound like separate words, but in other ways sound like they are joined to the word that follows. In the dictionary, as in other literacy materials that have been printed since we started using this spelling system with the community, the proclitics are written separately. This is done to try and keep words as short as possible, which makes it easier for people learning to read and write. An entry in the dictionary that is preceded or followed by '-' means that the form is a prefix or a suffix. Prefixes join on to the beginning of words. For example, to qiat 'taro' we can add di- to form diqiat 'taro leaf'. Suffixes join onto the ends of words. So matan with $-\bar{n}$ on the end means 'your eye', whereas matan with $-n$ on the end means 'her eye' or 'his eye'.

\section{Bislama in the dictionary}

This is a trilingual dictionary, with definitions of Vurës words given in both English and Bislama. All Vurës people are fluent in Bislama. Some use Bislama on a daily basis, but many use it less regularly, only when they come into contact with people who do not speak Vurës. While Vurës people are fluent speakers of Bislama, there is variation in the extent to which people are used to writing it. Most people have been taught literacy skills in English, but have not been systematically taught how to write Bislama. For this reason, not just on Vanua Lava, but throughout Vanuatu, it is quite common for people to be reasonably unsystematic in the way that they spell Bislama. Bislama is an English-lexifier creole. This means that the majority of words have an English origin. Due to this, many people who are more used to writing in English than in Bislama will transfer their knowledge of English spelling, even if the pronunciation and meaning of the word in Bislama is quite different. When writing Bislama, many people use a mix of English spelling combined with some knowledge of Bislama spelling conventions. 
Bislama spelling conventions do exist. There has been somelevel of standarisation of Bislama spelling, which started in the 1970s when the first Bislama translations of the gospels were produced (Crowley 2004). Since Independence in 1980, as part of the promotion of Bislama as the national language of Vanuatu, many groups with an interest in literacy advocacy, particularly the Literacy Association of Vanuatu, have further developed the standarisation of the written form of Bislama. For the most part, the spelling of Bislama in this dictionary follows the standardised spelling used in A New Bislama Dictionary (Crowley 2003). The only deviations from the spelling presented in Crowley (2003) are in rare cases where experience tells me that the spelling does not reflect the most widespread current pronunciation. Pronunciation does vary within Vanuatu and I decided to consistently use the spelling that is seen as being the most common on a national level.

There is variation, not just in pronunciation and spelling, but also in the words of Bislama. The majority of words are commonly used across the country, but others, especially those derived from local languages, can be limited in use to a particular area. Again, where this is the case, I have tried to represent as much as possible a standard national form of Bislama. For example, with plant names, if Crowley (2003) gives a word that is clearly derived from a word in Vanuatu languages, then I use only that word as the definition if I am sure that knowledge of that word is completely widespread. If there is any doubt regarding knowledge of any Bislama words, then the definition will consist of an explanation of the meaning in simple Bislama.

\section{The Vurës corpus}

This dictionary was compiled from data collected over a 20-year period, from March 1999 to the end of 2018. The majority of headwords have been taken from and are represented multiple times in a corpus totalling approximately 32.5 hours of recorded speech of a variety of genres. Approximately half of these recordings are audio only and the remainder are video and audio. The majority are monologues. The majority of the texts do not include any form of elicitation, but rather are people speaking in response to a request to explain a procedure, present a narrative, describe a situation, etc. The texts were recorded in two phases as part of separately funded projects, and thus are archived in different digital archives. The data collected in the period from 2002-06 was part of a project funded by the Endangered Languages Documentation Programme $(\mathrm{ELDP})^{3}$ and this data is archived both with the Endangered Languages Archive (ELAR), hosted by the School of Oriental and African Studies (SOAS), and with the Pacific and Regional Archive for Digital Sources in Endangered Cultures (PARADISEC). The second phase was funded by the Documentation of Endangered Languages project (DOBES), ${ }^{4}$ with data collected from 2007-13. 
The corpora in these digital archives are publicly available, and the access details and list of texts are presented in the appendix. For some entries, an example sentence illustrating the headword is presented. The majority of those example sentences has been extracted from recorded texts, and, if this is the case, a reference code for the relevant text is given after the example, to enable dictionary users to verify the use of the headword by accessing the text in one of the digital archives. The corpus was compiled with the primary goal of producing a grammatical description, published as Malau (2016). Compilation of a dictionary was a secondary aim. Thus, the definitions provided for some words are not as complete and thoroughly verified as for others.

The texts in the corpus represent the language of over 100 different speakers, ranging in age from young children to the oldest members of the community. There is no significant dialectal variation in Vurës and each of the main communities in different villages are represented in the corpus. The recordings for the ELDP project were all made by me. The recordings archived with the DOBES project were recorded by me and by two other members of that project team, Armstrong Malau and Katherine Holmes. Transcriptions and translations of the texts were produced by me in consultation with a number of speakers, the main language assistants being Armstrong Malau, Eli Field Malau, Kali Malau, Samson Blondel, Kathy Doris, and Welsam Segir Malau Qiat. For the most part, translations made with the help of language assistants were from Vurës into Bislama. At a later stage, I then translated the texts into English. As my competence in Vurës developed, I was able to refine both the Bislama and English translations. While working on translations, the language assistants helped with refining the definitions of many of the words in the dictionary. Definitions of many of the more common, everyday words are based less on direct consultation, and more on observations of the language in use. Over the past 20 years, I have spent a combined total of a little more than a year with the Vurës community and am married to a speaker, Armstrong Malau, thus I have daily exposure to the language. Although not fluent, I am a competent speaker of the language. I am a fluent Bislama speaker.

The majority of words, mostly nouns, in a number of semantic domains was directly elicited rather than documented through textual use. Marine biologist Katherine Holmes was a member of the DOBES project team and was responsible for documenting most of the marine terms, including names of fish, shellfish, and other marine species, and some fishing terminology. She has provided scientific identification for many species documented in the dictionary, mostly through spending time with speakers engaged in fishing and reef gleaning. Holmes checked identifications with multiple speakers, and scientific names for marine species are only given where the name has been checked and she was confident that the identification is correct. She also took almost all the photos of marine species that are presented to illustrate these nouns. 
Plants were identified by two botanists who work with the Vanuatu Department of Forestry, Sam Chanel and Philemon Ala. In the early stages of my documentation of the language, in 2002, I asked Sam Chanel for identifications of approximately 100 plants, and he identified these from specimens that I took and delivered to him at the Vanuatu Herbarium. Later, in 2007, Philemon Ala visited Vanua Lava and made further identifications, working with several Vurës speakers. Again, I have tried to give the scientific identification only when I am relatively confident that the scientific name is correct. Some of the better-known species that are distributed throughout Vanuatu, particularly food-bearing trees and plants, I was able to identify on my own, and by consulting Wheatley et al. (1992). The names and descriptions of some varieties of coconuts and taro cultivars have been recorded based on the research of agronomist Sophie Caillon.

The scientific identifications provided for bird names should be taken as less accurate, and are based solely on identifications from pictures in Bregulla (1992) and from my own experience in Vanuatu. As the bird life of Vanuatu is not incredibly diverse, these identifications can still be considered to be reasonably accurate, as there are not many instances of similar species that might easily be confused when identifying through images.

Anthropologist Sabine Hess provided some assistance with the definitions of kin terms. Linguist Daniel Krausse carried out fieldwork on Vurës as part of his $\mathrm{PhD}$ research in 2018 and contributed a small number of lexical items that were not yet included in the database and also provided modifications for some definitions.

In terms of technical aspects of the production of this dictionary, the lexical data was entered and stored in a database, using the FieldWorks Language Explorer (FLEx) software. ${ }^{5}$ All data was entered by me, regardless of whether it was produced as part of the process of text annotation, or as direct entry of elicited lexical data. A configured dictionary, finderlists and the thesaurus were exported using the Pathway program. This is a program that is linked to the FLEx program, which enables styles to be applied consistently to the dictionary data that is stored in separate fields in the database, so that the output is a somewhat formatted dictionary. The output files were then further formatted in Microsoft Word to improve the aesthetics and make the final product more user-friendly. There are just over 3,500 headword entries in the dictionary.

In order to produce the thesaurus, I added the semantic category of individual words as a field within the FLEx database. This is an inbuilt part of the program, with a very detailed ready-made set of semantic domains. For the most part, the divisions into semantic domains that are specified within FLEx matched the categories that I wanted to distinguish for Vurës, but in some cases I adjusted

$5 \quad$ FieldWorks is a set of software tools that have been created by the organisation SIL for storing and anlaysing language data. See: software.sil.org/fieldworks/. 
the domains to suit. I also added some new categories that were not included, such as having a specific category for taros and coconuts, as these are such a pervasive part of Vurës culture.

Due to my collaborations with Katherine Holmes, Chanel Sam and Philemon Ala, and the input of Sophie Caillon, this dictionary is quite heavily weighted towards names for flora and fauna, with close to one third of the entries belonging to these semantic domains. The dictionary includes 431 names for various fauna, of which 295 are marine species, including 158 fish species and 50 shellfish species. There are also 62 bird species included. There are 608 entries for plant names, including 228 trees and palms, 109 taro varieties, and a range of other plant and animal species.

Any words that occurred in a text as part of the corpus have been included. The emphasis on flora and fauna was intentional to the extent that I actively sought collaboration with a marine biologist and botanists, knowing that engagement with the marine and bush environments are important sociocultural emphases for the community. Most omissions are unintentional, in that this dictionary is simply the result of my best efforts at documenting the words of Vurës with the time and resources that I have had available. I have chosen to publish the dictionary as it stands so that it can be used by the community now, but with the hope that it will be added to in future.

One category of omissions that some users might observe is swear words. The inclusion of such words is an issue that can often be contentious when compiling a dictionary, particularly for small language communities. I have included words referring to body parts and functions that might be thought of as 'rude' by some, but I have not included words that are solely used for swearing. There were differing opinions as to whether these words should be included or not, and I decided that it was appropriate to respect the more conservative members of the community.

Almost all of the images used to illustrate headwords are photographs that have been taken by members of the DOBES team, specifically for the Vurës documentation project. Copyright belongs to the photographer and this is indicated by a watermark on each photo. Researchers who contributed photos are Katherine Holmes, Catriona Malau, Armstrong Malau, Philemon Ala, Raymond Ammann, Stefan Schnell and Sabine Hess. The only photos included that were not taken as part of the DOBES project are those depicting bird species. Permission to include these to illustrate bird names was kindly given by the photographer, Garry Innes, whose name is also watermarked on the photos that he contributed. 


\section{Structure of the dictionary and entries}

There are four sections to the dictionary itself. First comes the main part, which lists Vurës words in alphabetical order and gives meanings in English and Bislama and other kinds of information. This is a translation dictionary, which means that the meanings of the Vurës words are given in both English and Bislama, but the definitions or meanings of words are not given in Vurës itself. The different types of information that are provided about each word and how to find that information in an entry are explained below in Section 5.2. After the main part of the dictionary, there are two finderlists, one from English to Vurës and the other from Bislama to Vurës. A finderlist lets the user look up a word in English or Bislama and find the equivalent word or words in Vurës. There is not much information in the finderlist, compared to in the main part of the dictionary, so when the user finds the word that they are looking for, they can then go to the main entry for that word if they want more information. There is a short introduction at the beginning of each finderlist, which covers some important points about how the finderlists are set out. Finally, the last section is a thesaurus. This is where words are grouped according to a meaning-based category. For example, there are lists of all of the fish names in the language, and names for different food crops, like taros, yams or bananas, and many other things. Further explanation of the structure of the thesaurus, and the different categories that have been included, is provided at the beginning of the thesaurus.

\subsection{Alphabetical ordering}

In Section 2.1 an explanation was given about the letters used in Vurës spelling. In terms of alphabetical order used in the dictionary, as Vurës speakers know how to write in English, Bislama or French and the letters are based on letters for those languages, it was decided that the Vurës letters should be put together to form an alphabet in an order similar to that which is used for English. I thought that this was the most sensible decision and asked the opinion of a range of Vurës people over the years, who have all expressed agreement with the proposed order. Therefore, where the letters are exactly the same, they occur in that order. The only letters that are different are still based on English letters, so they follow that basic letter in the Vurës alphabet. For example, $\mathbf{e}$ is followed by $\overline{\mathbf{e}}$ and then $\ddot{\mathbf{e}}$. The alphabetical order of Vurës is as follows:

\section{a b d e è ëgi k l m m n ñ oōö pqrst u vw}

Looking at this alphabet, some people might wonder why some of the letters of the English alphabet are missing; that is $\mathbf{c}, \mathbf{f}, \mathbf{h}, \mathbf{j}, \mathbf{x}, \mathbf{y}$ and $\mathbf{z}$. There are two reasons for this. Mostly the reason is that the sounds that these letters represent for English do not occur in the Vurës language. This is the case for $\mathbf{f}, \mathbf{h}, \mathbf{j}$ and $\mathbf{z}$. In other cases, this is due to the fact that the English spelling system is actually 
not very regular. For example, in English c can either represent the same sound as $\mathbf{k}$, or $\mathbf{c}$ can represent the same sound as $\mathbf{s}$. Vurës spelling simplifies spelling by consistently using either the letter $\mathbf{k}$ or $\mathbf{s}$, and not using $\mathbf{c}$ at all.

\subsection{Structure of the entries}

The entries in the dictionary vary in terms of how many different types of information are given about each word. At the very least, for each word, the part of speech is given, followed by the meaning in English, then the meaning in Bislama, as in the following:

butöliaw n.com. rainbow $\sim$ renbo

Other entries contain much more information. Here are five sample entries, to explain. Each part of each of these entries has a raised red number after it, and below there is an explanation for each number about what category of information that is. Note that different styles of typing fonts and different colours are used to try to distinguish one kind of information from the information next to it, in order to make it easier to find different types of information.

$\operatorname{ar}^{12}{ }^{2}$ (fr.var. waar) $)^{3}$ n.com. ${ }^{4}$ kind of tree ${ }^{6}$

$\sim$ wan kaen tri ${ }^{7}$ Premna corymbosa ${ }^{8}$

[Used for making bows. Ol i yusum blong mekem bonaro. $]^{13}$ [POc * qarop 'Premna spp.'] ${ }^{16}$

$\mathbf{l e n}_{1}^{1}{ }_{1}^{2}$ n.com. ${ }^{4} \mathbf{1} \cdot{ }^{5}$ wind $^{6} \sim$ win $^{7} \mathbf{O}$ leñ nē ge meneg, o len mö uv me, ni tek nē in̄kē, ni tek nē in̄kè. ${ }^{9}$ The wind was strong, the wind blew this way and it took it (bird) this way, it took it this way. ${ }^{10}$ Win $i$ strong, win i blu i kam, $i$ tekem hem (piin) olsem ia, i tekem hem olsem ia. ${ }^{11}(\mathrm{DHN})^{12} \mathbf{2} \cdot{ }^{5}$ air $^{6} \sim$ win $^{7}$ La masawre nē me le o leñ timiak in̄kē, ni rōñteg o bunë. ${ }^{9}$ When he took in the wind like that, he sensed a smell. ${ }^{10}$ Taem hem i tekem win olsem ia, hem i harem wan smel. ${ }^{11}(\mathrm{RTF}){ }^{12}\left[\mathrm{POC}\right.$ *lanit 'sky'] ${ }^{16}$

len̄limerlav ${ }^{18} \quad$ (comp. $)^{19} \quad$ n.com. $^{4}$ southeast tradewind $^{6} \sim$ tokelau, saotis win we $\mathrm{i}$ kam long Mere Lava ${ }^{7}$ \{Lit. wind from Mere Lava win i kam long Mere Lava\} ${ }^{15}$

$\mathbf{l o}^{1}{ }_{1}^{2}$ n.loc. ${ }^{4}$ seashore, seaside, area by sea, but not including sea itself $^{6}$ solwota, eria klosap long solwota ${ }^{7}$ See: naw ${ }_{1}^{14}\left[\right.$ POC *laur 'sea, seawards'] ${ }^{16}$ $\mathbf{l o}_{2}{ }_{2}^{2}$ art. ${ }^{4}$ locative preposition, to, at, on, marking common nouns ${ }^{6} \sim$ long $^{7}$ No mēèl nēk lo sto. ${ }^{9}$ I sawyou at the shop. ${ }^{10}$ Mi lukim yu long stoa.11 (Allomorphs: la, le, lē, lë, li, lō, lö) ${ }^{17}$ See: $\mathrm{a}_{1}^{14}$

Entries within the dictionary are organised as follows:

1. Headword: The Vurës word is the first part of any entry in the dictionary. The Vurës headword is presented the way that it is most commonly pronounced. Note that in Vurës, words mostly don't change their shape (i.e. there is little allomorphy). A common exception is with nouns that take endings that show who owns the thing expressed by the noun (possessive suffixes). See the discussion of nouns in 5.3 for more explanation. 
2. Homonym number: Sometimes there are two words in a language that sound exactly the same, and therefore are spelt the same, but have completely different meanings. These are called homonyms. If words are homonyms, they are listed separately, with their separate meanings, as they are different words. For example, Vurës lo is both an absolute location noun meaning 'seashore, seaside' and an article that is used before common nouns. These are totally different words and it is just a coincidence that they sound the same. In cases like these, the headword is followed by a number, indicating which homonym entry it is. This is particularly important for when a different entry makes a reference to the entry for a word that is a homonym.

3. Variant: For some words, there is more than one way in which the word can be pronounced, and therefore spelt. This can be for different reasons. Types of variants are explained in Section 5.4. For all words that have variants, the headword that is given is the most common or easily identifiable for speakers of the language, and the variant is in brackets after the headword. Within the brackets is a label for the type of variant, and then the word itself, like this: (fr.var. waar).

4. Part of speech: After the Vurës word is an abbreviation label in small font for the part of speech of the word. That is, whether it is a noun, a verb or some other type of word. Some words belong to more than one category. The part of speech is given in italics: n.com. There is a full list of the abbreviations used, with some further explanation, in Section 5.3.

5. Sense number: Some words have more than one meaning or slight variations in their meaning. We call these different meanings the senses of the word. For example, bē can refer to fresh water or to a river. These meanings are obviously related to each other, but they are not the same, so they need to be listed separately under the entry, with distinct meanings and other information. The start of a sense is indicated with a number, like this: $2 \cdot$. Words can have up to five senses.

6. English meaning: The English meaning is given next. In some cases this can be just one word, but other Vurës words require a much longer English definition.

7. Bislama meaning: The Bislama translation or meaning comes after the English. It is separated by and is in a different colour to make it easy to distinguish the Bislama definition from the English.

8. Scientific name: For many plants, animals, fish and birds, a scientific name has been given. See Section 4 for more on this.

9. Example sentence: An example sentence in Vurës has been included for as many words as possible, to help illustrate the meaning and use of the word. This is not necessary for things like names of plants and fishes, which usually have other types of information like a description of their appearance, or a photo.

10. English translation: An English translation of the example sentence follows the Vurës example. 
11. Bislama translation: A Bislama translation of the example sentence then follows the English translation.

12. Reference: Where an example sentence has been provided, in some cases it is followed by a reference abbreviation in brackets: (DDL.006). If a reference is given, the example sentence was taken from a recording of a Vurës speaker. The reference is a label for the particular recording. The recordings and where they can be found on the internet are listed in the Appendix at the back of the dictionary, so anyone interested can listen to these examples.

13. Encyclopedic information: For some entries, additional encyclopedic information has been provided in square brackets like this: [English. Bislama.]. This information is not an essential part of the meaning of the word, but it aids in understanding the meaning and use of the word.

14. Lexical relations: In some cases there are two words that have the same or very similar meanings. These are called synonyms and are indicated with the label Syn. For example, Syn: gösuv occurs as part of the entry for as. For some words, there is a word that is almost exactly the opposite in meaning. These are called antonyms and are indicated with the label Ant. For example, Ant: mamas occurs as part of the entry for döw. Other words are related in meaning in some way, which is worth drawing to the attention of users of the dictionary. For example, See: naw occurs as part of the entry for lo 'seaside', because the two words have similar meanings and the range of use of the words lo and naw is a bit different to the way the words 'sea' and 'seaside' are used in English, and 'solwota' in Bislama.

15. Literal meaning: For some words, especially compounds formed from two or more other words, the meaning of the compound is not obvious from the words that make up the compound. In cases like these it is of interest to know what the individual words mean. For example, the expression gen mōvōt means 'close one's eyes', but this is an idiom formed from the words meaning 'eat' and 'sleep'. Literal meanings are indicated towards the end of the entry, like this: \{Lit. eat sleep kakae slip\}.

16. Etymology: Two different but related types of information are listed in square brackets at the very end of a small number of entries. This information is about the historical origin of the word. More detail about this is given in Section 6. The etymological information is presented in square brackets like this: [POC *qarop 'Premna spp.'] with a label indicating the source language.

17. Allomorphs: As mentioned at note 1, there is little allomorphy in Vurës. A significant exception is with some proclitics and prefixes that are important to the grammar of the language. The vowels in these forms match the vowel of the word they occur before. So one says in Vurës, for example, lo sto 'at the shop', but le ev 'in the fire' and lö gövur 'at the house'. See Malau (2016: 44-47) for a detailed explanation of this vowel variation. 
18. Subentries: Some entries include a subentry. A subentry is a complex form that contains the main entry headword. Subentries are indented after the main entry and can themselves include all the same information as a main entry.

19. Complex form type: For subentries, the subentry headword is always made up of more than a single morpheme - word or unit of meaning - like a compound or a reduplicated form. This is indicated with an abbreviation label in brackets after the headword, like this: (comp.). There are six different types of complex forms and explanations and abbreviations for these are given in Section 5.4.

Some of the entries have pictures to help illustrate the meaning. The picture is always located at the end, directly below the entry that it relates to.

\subsection{Part of speech labels used}

The part of speech or word class labels used in the dictionary reflect the analysis of word classes presented in Malau (2016). The abbreviations used for each word class and subclass are presented in Table 2. Readers who would like to know more about the properties of particular word classes are directed to the main section of the grammar in which that word class is discussed. The relevant page numbers are provided in the last column of Table 2. A few points that are particularly relevant are discussed briefly here.

Table 2: Parts of speech in Vurës

\begin{tabular}{|l|l|l|}
\hline Abbrev. & Part of speech label & Reference \\
\hline adj. & Adjective & $117-120$ \\
\hline adv. & Adverb & $122-124$ \\
\hline art. & Article & $230-241$ \\
\hline cl. & Relational classifier & $290-308$ \\
\hline conj. & Conjunction & $700-728$ \\
\hline dem. & Demonstrative & $423-460$ \\
\hline dir. & Directional particle & 132 \\
\hline inter. & Interjection & 138 \\
\hline loc. & Locational & 131 \\
\hline loc.adj. & Locational adjunct & 131 \\
\hline mod. & General modifier & 124 \\
\hline n.com. & Non-suffixing common noun & $107-108$ \\
\hline n.com.suff. & Suffixing common noun & $108-109$ \\
\hline n.loc. & Absolute location noun & $105-106$ \\
\hline n.p.bound & Bound proper noun & $104-105$ \\
\hline n.p.fr. & Free proper noun & $103-104$ \\
\hline & & \\
\hline
\end{tabular}


A DICTIONARY OF VURËS, VANUATU

\begin{tabular}{|l|l|l|}
\hline Abbrev. & Part of speech label & Reference \\
\hline num. & Numeral & $124-127$ \\
\hline part. & Particle & 134 \\
\hline pre. & Prefix & 135 \\
\hline prep. & Preposition & $313-370$ \\
\hline pron. & Pronoun & $127-128$ \\
\hline quant. & Quantifier & $120-121$ \\
\hline subord. & Subordinator & $136-137$ \\
\hline suff. & Suffix & 128,135 \\
\hline temp. & Temporal & $121-122$ \\
\hline v. & Ambitransitive verb & $116-117$ \\
\hline vi. & Intransitive verb & $110-114$ \\
\hline vt. & Transitive verb & $114-116$ \\
\hline v.part. & Verbal particle & $134-135$ \\
\hline
\end{tabular}

In Vurës there is a considerable degree of word class flexibility (Malau 2016: 139-145). This means that, as in English, there are many words that can be used as different parts of speech, in particular both as a noun and as a verb. For words like this, the meanings of the word as different parts of speech are presented as different senses of the word. The following entry for tañsar provides an example of how this looks in the dictionary:

tan̄sar $\mathbf{1} \cdot n . c o m$. person $\sim \operatorname{man} \mathbf{2} \cdot v i$. become a person, feel like you have become human again $\sim$ kam man

Following on from this example, note that if all senses of a word belong to the same part of speech category, the part of speech is indicated directly after the headword, before the sense numbers and their associated definitions. If, as with tañsar, the parts of speech are different, then it is indicated after the sense number for each sense.

As stated, this word class flexibility occurs particularly with words that can be both nouns and verbs. To a lesser extent, there is also some overlap for words in other categories. For example, very much like in English, timiak 'like' is a preposition, a transitive verb, a subordinator and a discourse particle. Again, this will be indicated through the different senses.

There are five noun subclasses in Vurës. It is important when speaking Vurës to know which subclass a noun belongs to for two main reasons. One is that the subclass of noun determines which article the noun will occur with. The other reason is that some nouns - bound proper nouns and suffixing common nouns - have a suffix attached to indicate the possessor of the item referred to by the noun. When it comes to flexibility, some nouns can occur as a member of more than one subclass. A helpful example to illustrate both the different classes and subclasses, and also the flexibility is with the words that mean 'dad, 
father'. Mam 'Dad', when used as an address term or to refer to one's own father is a free proper noun, and as such can be preceded by the personal article $i$. When used to refer to a member of the generic class 'father, dad', mam is a nonsuffixing common noun and will be preceded by the common article $o$. The word mam also occurs as a transitive verb meaning 'to call someone father'. In order to say whose father someone is, you need to use a different word, which is a bound proper noun and takes a suffix to show the possessor. So tëmëk means 'my father', taman is 'her/his father' and temen $i$ Kali means 'Kali's father'. These examples show how the nouns show variation in the vowels of the root, depending on the possessor. The rules about how the vowels change are quite complicated and readers who wish to know more detail should refer to Malau (2016: 276-281). Due to this complexity, for each bound proper noun, the form listed in the dictionary is that which occurs when the possessor is a noun. Then, to illustrate the allomorphy (the variation in the vowels within the word), first person singular ('my') and third person singular ('her/his/its') possessed forms are presented as subentries. Suffixing common nouns behave in the same way, so they are also presented in this way.

The main division for the class of verbs in Vurës is into intransitive, transitive and ambitransitive subclasses. Intransitive verbs are labelled in the dictionary as $v i$. and transitive verbs as $v t$. For ambitransitive verbs, if the meaning difference between the intransitive and transitive uses of the verb is significant, then these are listed as separate senses of the word, with the meaning and label given for each sense. If, however, there is no significant meaning and distribution differences for a verb that can be used both intransitively and transitively, then the part of speech label given is simply $v$. For example, garmöo means 'spit' as an intransitive verb and 'spit on' as a transitive verb. It is thus just marked as $v$. with the definition 'spit, spit on'.

There are a number of entries for which the occurrence of the verb is limited in the corpus, and thus it has not been possible to determine conclusively the range of transitivity for the verb. In these cases, the word class is also indicated simply as $v$.

\subsection{Variants, variation and complex forms}

In Vurës, there is almost no dialectal variation. It is less than two hours walk between each of the villages within the original Vurës area and people from these villages are in regular contact. Instead, most variation that occurs is free variation; that is, alternate forms can be used freely by speakers. This is particularly the case with the pronunciation of some vowels, especially the two vowels $\ddot{\mathbf{e}}$ and $\overline{\mathbf{e}}$. There are some words that contain the vowel $\ddot{\mathbf{e}}$, for which some speakers, particularly younger people, replace the ë with e. For example, dëm 'yam' is pronounced as dem by most people today. Older speakers note that the original pronunciation was dëm. Similar variation occurs with the vowel $\overline{\mathbf{e}}$, which some speakers pronounce as $\mathbf{i}$ in some words. For example, the first person plural inclusive pronoun, 'we, us' is nēn, but is sometimes 
pronounced as nin. In the dictionary, the pronunciation that has been observed most commonly is given as the headword, with the other pronunciation given afterwards in brackets: (fr.var. dëm).

There are two other types of variants that are identified in brackets after the headword. One is common abbreviated forms of a word, such as timiak 'like', which is frequently reduced, and pronounced as tiak and so this is given as a variant after the headword preceded by the label abbrev. The other variant type indicated is for a small number of words for which the root of the word does not occur very often on its own, but is generally fused with a word that comes before it, which is usually a separate word. For example, the article that goes before place names, $\mathbf{a}$ is usually a separate word and would be written as such. There are a few exceptions to this, such as the word for 'where', for which a joins with vē to form a single word avē. As speakers think of avē 'where' as the word for 'where', with the a attached, it makes more sense to list this as the headword. The root, which is generally not thought of by speakers as occurring on its own, is listed after as a variant: (root vē).

There are several different types of complex word forms that are listed as subentries in the dictionary. By complex form, I mean a word that is made up of more than one word or a word with another morpheme attached. This means, a single word with two different elements contributing to the meaning. For each subentry, the specific type of complex form is indicated with an abbreviation in brackets after the headword. The different types are explained here:

- Compound (comp.): A compound is a word that is formed from two or more other words put together. In Vurës these words are mostly nouns that are formed from one noun plus another noun or verb following it. Compounds are quite common as a way of making new nouns for different plants and animals that are related or similar. For example, under mōto 'coconut' in the dictionary are many different types of mōtō. Most of the names of different types of coconut are compounds, with the name being the word mōtō followed by another word, such as mōtō dēdērēs, which is the name of a type of coconut that has sweet flesh, with dēdērēs meaning 'sweet'. Compounds can be made up of more than one other word. For example, wotag dere timiat is a kind of nut that has dark red skin, and so it is named for the dere 'blood' of the timiat 'devil'.

- Possessed noun (n.poss): When some nouns are indicated for their possessor, or owner, especially parts of the body and names for family, the form of the root of the word changes. For example, the word for 'father' is teme, but 'my father' is tëmëk and 'his father' is taman. For each noun that changes its form in this way, the root noun is listed as a headword, and the forms for 'my X' and 'her/his/its X' are listed as subentries to show the variation.

- Reduplicated form (redup.): Reduplication, the repetition of a word or part of a word to form a new word, is a very common process in Vurës. In some cases, the reduplication is a regular process, and adds to, but does not really change, the meaning, such as indicating that an action continues for 
an extended period of time. (See Malau 2016: 172-197 for details.) In other cases, reduplication can form a new word that has a meaning that is not entirely predictable from its parts, and belongs to a different part of speech category. For example, the verb gen 'eat', when reduplicated, can be a noun, gengen 'food'. As this meaning is not predictable - and this is particularly the case when verbs are reduplicated to form nouns - then the form gengen and others like it must be listed separately in the dictionary. They are listed with (redup.) following the headword.

- Serial verb construction (SVC): Serial verb constructions, when two or more verbs are used in combination, are common in Vurës. (See Malau 2016: 557620 for details.) In some cases, the meaning resulting from the combination of verbs is not predictable. In these cases, the serial verb construction is included as an entry in the dictionary, followed by (SVC).

- Derived form: A headword is listed as (der.) if it has been formed by adding a derivational prefix or suffix to an original word to form a new word. For example, there is a prefix, w0-, that is used to form new nouns, from other verbs, nouns, or combinations of nouns and verbs. The meaning and form of the words produced using the prefix is not predictable. An example of this is the noun wōtōtōw 'measuring stick', which is derived from the verb tōw 'to measure' reduplicated with the w0- prefix attached.

- Idiom (id.): An idiom is an expression, formed from a combination of words, the meaning of which is not at all predictable from the meaning of the individual words. An example is, qaq tala lam, which means 'Bislama'. The literal meaning of this expression is 'the language (qaq) of the deep sea (lam)'.

\section{Word origins}

The Vurës language belongs to the grouping called Oceanic within the Austronesian language family. Oceanic languages include most of the indigenous languages spoken in the Pacific region nations. They all share a common ancestor language, which means that they have a common source (Lynch et al. 2002). The ancestor of all Oceanic languages is known as Proto Oceanic. Proto Oceanic can be thought of as the great-great-granddaughter of Proto Austronesian, which sits at the top of the family tree. The languages of the islands of Torba are all very closely related to each other, so they can be thought of as sisters, whereas languages of central and southern Vanuatu are like cousins to Vurës, and Polynesian languages are more distant cousins. Most of the words in Vurës, and thus most of the words in this dictionary, are indigenous to the language and this means that they have been inherited from Proto Oceanic. The group of Oceanic languages, which has about 450 members, has been well studied, as has the history of the development of the languages from Proto Oceanic. As such, we can often tell from the form of a Vurës word, comparing it to words in other Oceanic languages, roughly what that word must have sounded like in Proto Oceanic. It is useful for those who study relationships 
between languages, to know which words can be traced back to the ancestor language. Some reconstructions are thus included in the dictionary, where they are known. These occur at the end of an entry in square brackets, with the format $\left[\mathrm{POC}{ }^{*}\right.$ word 'meaning'], POc being the abbreviation for Proto Oceanic. All of the Proto Oceanic reconstructions presented come from four volumes on The Lexicon of Proto Oceanic (Ross, Pawley and Osmond 1998, 2003, 2008, 2011).

In the majority of cases where I have provided a reconstruction of a word, this is for the word in Proto Oceanic. In some cases, a confident reconstruction for Proto Oceanic has not been produced, but it has been possible to trace back to a more immediate ancestor, Proto North Central Vanuatu. These reconstructions are from Clark (2009) and are preceded by the label PNCV.

The national language of Vanuatu, Bislama, is a creolised pidgin language most of whose words have come from English. All speakers of Vurës are also fluent speakers of Bislama and use it quite regularly to communicate with outsiders - people who are from Vanuatu but do not know Vurës. As a result of regular contact and use, today some of the words that are used in Vurës are not words that have been handed down into the language from the ancestor language, but which instead have come from Bislama. In some cases, a Bislama word might have almost completely replaced the original Vurës word, such that almost no one today uses the original word. An example of that is taosen replacing tar 'thousand'. The word tar is still known by many, but rarely used. Alternatively, a word might be used quite regularly, although the original word is still known and used by most people. An example of such is wok, which is used by many in place of wiwieg 'work'. In other cases, the word derived from Bislama is the only word used, because it refers to an item or concept that has recently been introduced, since Europeans settled in Vanuatu. These are words like trak to refer to cars and other vehicles, derived from English 'truck'. Words like these, although not of Oceanic origin, are used on a daily basis when speaking Vurës and have been included in the dictionary. Some speakers of the language may not approve of this, because they feel that it is not 'real' language, but nevertheless as they are well incorporated into the language, it is an accurate reflection to include them. Words that have come into the language from Bislama are indicated with [Bis Bislama word 'English meaning'] at the end of the entry. If the word borrowed from Bislama has the same meaning as a word that already exists in Vurës, then this is indicated with See: word [Bis].

\section{References}

Bregulla, Heinrich L. 1992. Birds of Vanuatu. Shropshire, England: Anthony Nelson.

Clark, Ross. 2009. *Leo Tuai: A Comparative Lexical Study of North and Central Vanuatu Languages. Pacific Linguistics 603. Canberra: The Australian National University.

Crowley, Terry. 2003. A New Bislama Dictionary. (2nd Edition) Vanuatu: Institute of Pacific Studies, University of the South Pacific. 
Crowley, Terry. 2004. Bislama Reference Grammar. Oceanic Linguistics Special Publication No. 31. Honolulu: University of Hawai'i Press.

François, Alexandre, Michael Franjieh, Sébastien Lacrampe, and Stefan Schnell. 2015. The exceptional linguistic density of Vanuatu: Introduction to the volume. In Alexandre François, Sébastien Lacrampe, Michael Franjieh, Stefan Schnell. The Languages of Vanuatu: Unity and Diversity, 5, Asia-Pacific Linguistics Open Access, pp.1-21, 2015, Studies in the Languages of Island Melanesia.

Lynch, John. 2000. Linguistic subgrouping in Vanuatu and New Caledonia. In Proceedings of the Second International Conference on Oceanic Linguistics (SICOL), vol. 2 Historical and descriptive studies, ed. by Bill Palmer and Paul Geraghty, 155-184 Canberra: Pacific Linguistics.

Lynch, John, Malcolm Ross, and Terry Crowley. 2002. The Oceanic Languages. Richmond, Surrey: Curzon.

Malau, Catriona. 2016. A Grammar of Vurës, Vanuatu. Berlin, Boston: De Gruyter Mouton.

Ministry of Education. 2012. Vanuatu National Language Policy. Republic of Vanuatu. moet.gov.vu/docs/policies/Vanuatu $\% 20$ National $\% 20$ Language $\% 20$ Policy $\% 20$ (English)_2012.pdf

Ross, Malcolm, Andrew Pawley, and Meredith Osmond (eds). 1998. The Lexicon of Proto Oceanic. Volume 1: Material culture. Pacific Linguistics C-152. Canberra: The Australian National University.

Ross, Malcolm, Andrew Pawley, and Meredith Osmond (eds). 2003. The Lexicon of Proto Oceanic. Volume 2: The physical environment. Pacific Linguistics 545. Canberra: The Australian National University.

Ross, Malcolm, Andrew Pawley, and Meredith Osmond (eds). 2008. The Lexicon of Proto Oceanic. Volume 3: Plants. Pacific Linguistics 599. Canberra: The Australian National University.

Ross, Malcolm, Andrew Pawley, and Meredith Osmond (eds). 2011. The Lexicon of Proto Oceanic. Volume 4: Animals. Pacific Linguistics 621. Canberra: The Australian National University.

Stebbins, Tonya N. 2012. Mali (Baining) Dictionary. Studies in the Languages of Island Melanesia. Canberra: Asia-Pacific Linguistics.

Wheatley, J.I., M. Tebbs, S. Seoule, and Sheila Gowers. 1992. A Guide to the Common Trees of Vanuatu: With Lists of Their Traditional Uses \& Ni-Vanuatu Names. Port Vila, Vanuatu: Department of Forestry. 


\section{Abbreviations used in the dictionary}

\section{Grammatical categories}

adj.
adv.
art.
cl.
conj.
dem.
dir.
disc.
inter.
loc.
loc.adj.
mod.
n.loc.
n.p.bound.
n.com.
n.p.fr.
n.com.suff.

num.

part.

pre.

prep.

pron.

quant.

subord.

suff.

temp.

v.

$v i$.

$v t$.

v.part.
Adjective

Adverb

Article

Relational classifier

Conjunction

Demonstrative

Directional particle

Discourse particle

Interjection

Locational

Locational adjunct

General modifier

Absolute location noun

Bound proper noun

Common noun

Free proper noun

Suffixing common noun

Numeral

Particle

Prefix

Preposition

Pronoun

Quantifier

Subordinator

Suffix

Temporal

Verb

Intransitive verb

Transitive verb

Verbal particle

\section{Other abbreviations}

abbrev.

Ant

Bis

comp.

der.

dl.

Eng

excl.

fr.var.

Gen

id.

incl.

Lit.

n.poss

pl.

PNCV

POC

redup.

Spec

SVC

Syn
Abbreviation

Antonym

Bislama

Compound

Derived form

Dual

English

Exclusive

Free variant

Generic

Idiom

Inclusive

Literally

Possessed noun

Plural

Proto North-

Central Vanuatu

Proto Oceanic

Reduplicated form

Specific

Serial verb construction

Synonym 
This text is taken from A Dictionary of Vurës, Vanuatu, by Catriona Malau, published 2021 by ANU Press, The Australian National University,

Canberra, Australia.

doi.org/10.22459/DVV.2021.01 